\title{
Statistical And Correlation Studies of Ground Water Parameters Of Kamleshwarpur Area At Mainpat, (CHHATTISGARH)
}

\author{
Komal Kumari \\ ${ }^{I}$ Research Scholar, Department of Chemistry, Dr.C.V.Raman University, Kota, Kargi Road, Bilaspur (C.G.),
}

\begin{abstract}
Statistical analysis of ground water of kamleshwarpur area at Mainpat, was carried out to study the correlation between various physico-chemical parameters. Eleven water quality parameters of ground water of this area were estimated standard methods and procedures of sampling and estimation. $\mathrm{pH}$ of drinking water is an important parameter and it is correlated with ten parameters. It may be suggested that $\mathrm{TH}, \mathrm{Mg}^{++}$, TDS, TSS and fluoride are positively correlated with $\mathrm{pH}$ but Conductivity, Total Alkalinity and $\mathrm{Cl}^{-}$are negatively correlated with $\mathrm{pH}$. Calcium and Iron showed no relation with $\mathrm{pH}$. The Iron value of ground water is also above the permissible limit.
\end{abstract}

Keywords: - Correlation Coefficient, Ground water, Iron, Mainpat, Statistical Analysis

\section{INTRODUCTION}

Water, Air and Food are three basic needs in human life. Among which the three water occupy 1/3 portion of the hole globe. Sixty percent of whole body weight in human body weight in human body is occupied by water. According to Central Pollution control Board, $90 \%$ of the water supplied in India to the town and cities is polluted, out of which only $1.6 \%$ gets treated. Therefore, water quality management is fundamental for the human welfare [1][2]. Water plays an important role in the world economy, as it functions as a solvent for a wide variety of chemical substances and facilitates industrial cooling and transportation [3]. The quality of water is vital concern for mankind since it is directly linked with human welfare and sustainable development. It is necessary, therefore, to regularly monitor the quality of ground water. Thus, the present investigation is aimed to assess the groundwater quality of kamleshwarpur area special reference to their suitability for drinking purpose and correlated with physico-chemical parameter.

The Mainpat plateau is located about $45 \mathrm{~km} \mathrm{SSE}$ of Ambikapur, the district Head quarter of the Surguja. The area is conveniently approachable in all seasons by well connected by road, from the District Head quarter $(45 \mathrm{~km})$ and that reaches up to the top of the plateau. The nearest rail head is Bishrampur (SE Railway) situated at a distance of $65 \mathrm{~km}$ from the study area and nearest airport is Raipur (Chhattisgarh). Sitapur is the main townships and sub district headquarters $28 \mathrm{~km}$ from the study area. The study area is occupied by Mainpat plateau which is covered by Deccan Traps. The average height of the plateau is $1080 \mathrm{~m}$ and maximum height is $1165 \mathrm{~m}$ above MSL at Parpatia village on Mainpat in the western side of the plateau. The top of the whole plateau is covered by laterite and bauxite.

\section{GEOGRAPHICAL SITUATION OF MAINPAT}

The area is situated in Surguja District of Chhattisgarh. The Bharat Aluminium Company (BALCO), Korba has established its branch office there for extraction of aluminium from its ores. The average temperatures in winter and summer are $11-15^{\circ} \mathrm{c}$ and $22-25^{\circ} \mathrm{c}$ respectively. Its latitude and longitude vary from $22^{0} 45^{\prime}-22^{0} 53^{\prime}$ to $83^{0} 18^{\prime}-83^{0} 25^{\prime}$. It is spread over $29 \mathrm{~km}$ is length and $12 \mathrm{~km}$ breadth. Its peak height is $1152 \mathrm{~m}$ and height from seashore is $990 \mathrm{~m}$. It is the main tourist spot of Chhattisgarh.

III.

\section{MATERIALS AND METHOD}

Eleven physico-chemical parameters of water samples carried out in the laboratory according to APHA (1995) [4], Trivedi and Goel [5] while $\mathrm{pH}$ of water samples were recorded at the sampling sites. The relationship between two parameters $\mathrm{X}$ and $\mathrm{Y}$ expressed as correlation coefficient, $\mathrm{r}$ by well- known equation-

$$
\begin{gathered}
r=\frac{\sum(\mathrm{X}-\overline{\mathrm{X}})(\mathrm{Y}-\overline{\mathrm{Y}})}{\sqrt{\sum(\mathrm{X}-\overline{\mathrm{X}})^{2} \sum(\mathrm{Y}-\overline{\mathrm{Y}})^{2}}}------(1) \\
r=\frac{\sum \mathrm{XY}-\overline{\mathrm{X}} \sum \mathrm{Y}}{\sqrt{\left(\sum \mathrm{X}^{2}-\overline{\mathrm{X}} \sum \mathrm{X}\right)\left(\sum \mathrm{Y}^{2}-\overline{\mathrm{Y}} \sum \mathrm{Y}\right)}}------(2)
\end{gathered}
$$


The correlation coefficient $(r)$ shows that +1 , will be perfect positive correlation, -1 will be negative correlation and zero shows that no definite relationship. The value of $r$ will be positive sign will represent that the $\mathrm{Y}$ will increase with increasing $X$ value and otherwise for decrease values. This way analysis attempts to establish the nature of the relationship between the variables and thereby provides a mechanism for prediction or forecasting [6][7][8][9].

Table 1: Characterization of the Ground Water in Kamleshwarpur Area.

\begin{tabular}{|c|c|c|c|c|c|c|c|c|c|}
\hline S.N & Parameter & Min & Max & Range & Mean & MD & Variance & SD & SE \\
\hline 1 & $\mathrm{pH}$ & 6.0 & 7.0 & 1.0 & 6.50 & 4.33 & 0.25 & 0.5 & 0.28 \\
\hline 2 & Cond. & 102 & 105 & 03 & 103.67 & 69.11 & 2.33 & 1.52 & 0.87 \\
\hline 3 & TH & 238 & 246 & 08 & 242 & 161.33 & 16.0 & 4.0 & 2.30 \\
\hline 4 & $\mathbf{M g}^{++}$ & 232 & 238 & 06 & 234.67 & 156.44 & 9.33 & 3.05 & 1.76 \\
\hline 5 & $\mathrm{Ca}^{++}$ & 06 & 08 & 02 & 7.33 & 4.89 & 1.33 & 1.15 & 0.66 \\
\hline 6 & TA & 42 & 56 & 14 & 47.67 & 31.77 & 54.33 & 7.37 & 4.25 \\
\hline 7 & TDS & 40 & 42 & 02 & 41 & 27.33 & 1.0 & 1.0 & 0.57 \\
\hline 8 & TSS & 62 & 70 & 08 & 66.67 & 44.44 & 17.33 & 4.16 & 2.40 \\
\hline 9 & Cl & 06 & 09 & 03 & 7.33 & 4.89 & 2.33 & 1.52 & 0.87 \\
\hline 10 & Fluoride & 1.0 & 1.2 & 0.2 & 1.13 & 0.75 & 0.015 & 0.122 & 0.06 \\
\hline 11 & Iron & 2.0 & 2.2 & 0.2 & 2.07 & 1.37 & 0.015 & 0.122 & 0.06 \\
\hline
\end{tabular}

All values in $\mathrm{mg} / 1$ except $\mathrm{pH}$ and conductivity $(\mu \mathrm{mhos} / \mathrm{cm})$

Table 2: Correlation coefficient ( $r$ ) and Coefficient of Determination $\left(r^{2}\right)$ among the various Water Quality Parameters with Important Parameter $\mathrm{pH}$.

\begin{tabular}{|c|c|c|c|}
\hline S.N & Parameter & $\begin{array}{c}\text { Correlation Coefficient } \\
(\mathrm{r})\end{array}$ & $\begin{array}{c}\text { Coefficient of } \\
\left.\text { Determination( } \mathrm{r}^{2}\right)\end{array}$ \\
\hline 1 & $\mathrm{pH}$ & 1 & 1 \\
\hline 2 & Cond. & -0.37 & 0.13 \\
\hline 3 & $\mathrm{TH}$ & 0.5 & 0.25 \\
\hline 4 & $\mathrm{Mg}^{++}$ & 0.70 & 0.49 \\
\hline 5 & $\mathrm{Ca}^{++}$ & 0 & 0 \\
\hline 6 & $\mathrm{TA}$ & -0.20 & 0.04 \\
\hline 7 & $\mathrm{TDS}$ & 0.50 & 0.25 \\
\hline 8 & $\mathrm{TSS}$ & 0.97 & 0.94 \\
\hline 9 & $\mathrm{Cl}$ & -0.65 & 0.42 \\
\hline 10 & Fluoride & 0.72 & 0.51 \\
\hline 11 & Iron & 0 & 0 \\
\hline
\end{tabular}

Coefficient of $r^{2}$ is also calculated. It will be squared value of $r$. The value of $r^{2}$ ranges from 0 to 1 . It gives the measure of the proportion of variation in one variable associated with variations in the other.

\section{RESULT AND DISCUSSION}

Sampling station values (minimum and maximum) of eleven water quality physico-chemical parameters are presented in Table-1. Result obtained from the present study shows value of minimum, maximum, range, mean, mean deviation, variance, standard deviation (SD) and standard error (SE) for all the observed water parameters. All the parameters are within the permissible limit, except Iron (Fe). The concentration of $\mathrm{Fe}$ was found to above the permissible limit in all samples. The maximum permissible limit of $\mathrm{Fe}$ is $1.0 \mathrm{mg} / \mathrm{l}$ (IS: 10500-1991, BIS)[10]. The presence of Iron in ground water is due to rock formation. Iron is an essential element in human nutrition [11]. Although iron has got little concern as a health hazard but is still considered as a nuisance in excessive quantities [12]. It causes staining of clothes and utensils. The limits of iron are based on aesthetic and taste consideration rather than its physiological effects.

Table -2 reveals that the range of $r$ values and $r^{2}$ values for the relation amongst the water parameter with $\mathrm{pH}$. From the Table, it is clear that the $\mathrm{pH}$ value of groundwater lies between 6.0 to 7.0 , the average value being 6.50. Thus it was slightly acidic in most of the water samples analyzed. The average value are within the maximum permissible limits as per BIS norms. The range of permissible limits as per BIS drinking water is 6.5 to 8.5. The deviation of $\mathrm{pH}$ from the neutral water $\mathrm{pH}$ may be due to dilution of alkaline substances [13]. On, the above discussion at may be concluded that $\mathrm{pH}$ is an important physico-chemical water quality parameter. Positive correlation coefficient is observed in between $\mathrm{pH}-\mathrm{TH}(0.50), \mathrm{pH}-\mathrm{Mg}^{++}(0.70), \mathrm{pH}-\mathrm{TDS}(0.50)$, pH-TSS (0.97) and $\mathrm{pH}$-fluoride (0.72) while negative correlation is observed in between $\mathrm{pH}$-conductivity (-0.37), pH-TA $(-0.20)$ and $\mathrm{pH}_{-} \mathrm{Cl}^{-}(-0.65)$. However, $\mathrm{pH}-\mathrm{Ca}^{++}$and $\mathrm{pH}-\mathrm{Fe}$ are observed no definite relationship. 
The highest value of $\mathrm{r}^{2}$ is obtained pH-TSS (0.94) shows that $94 \%$ of variations in Total Suspended solids are influenced by $\mathrm{pH}$, however, the rest $6 \%$ variation can be attribute to other causes.

\section{ACKNOWLEDGEMENTS}

Author is thankful to Director and Dr. Manish Upadhyay Head, Department of Chemistry of Dr.C.V.Raman University Kota, Kargi Road Bilaspur (C.G.).

\section{REFERENCES}

[1]. Gupta, S.C., 1991. Chemical character of ground waters in Nagpur district,Rajsthan. Indian J. Environ. Health., 33(3), pp 341-349.

[2]. Madhuri, U.; Srinivas, T. and Sirresha, K., 2004. A study on drinking water quality in commercial area of Visakhapatnam. Poll.Res., 23(3), pp 405-409.

[3]. Upadhyay, M and Kumari, K., 2013. Analytical study of fluoride ion in drinking water around Ambikapur, Sarguja District, Chhattisgarh, India. International Journal of Engineering Research and Development, 5(9), pp 14-21.

[4]. APHA. 1998. Standard Methods for Examination of Water and Waste water. $20^{\text {th }}$ ed. American Public Health Association, New York. U.S.A.

[5]. Trivedy, R.K. and Goel ,P.K.1986. Chemical and Biological Methods for Water Pollution Studies. Env. Publication, KARAD. 415110.

[6]. Mulla, J.G. ; Farooqui, M. and Zaheer, A.,2007. A correlation and regression equations among water quality parameters. Int. J. Chem. Sci., 5(2), pp 943-952.

[7]. Draper, N.R. and Smith, H., 1966. Applied Regression Analysis- Wiley, New-York.

[8]. Snedecor, G.W. and Cohram, W.O., 1967. Statistical Method, The Lowa State University Press, Ames, $6^{\text {th }}$ Edn.

[9]. Kumar, J.; Jana, A.K.; Bansal, A. and Garg, R., 2005. Development of correlation between BOD and COD for refinery waste. Indian J. Env.Prot., 25(5), pp 405-409.

[10]. BIS. 1991. Specification for drinking water IS: 10500: 1991 Bureau of Indian Standards, New Delhi.

[11]. Moore, C.V. 1973. Iron In: Modern Nutrition in Health and Disease. Philadelphia, Lea and Febiger,p. 297.

[12]. Dart, F.J. 1974. The Hazard of Iron, Ottawa, Water and Pollution Control, Canada.

[13]. Kumari Sunita and Jha, A.K.2009. Assessment of drinking water quality in and around Patna.J. Poll. Research. 28(3): 507-509. 